\title{
UTILITY OF SEMIRIGID THORACOSCOPY IN THE DIAGNOSIS OF RECURRENT UNDIAGNOSED PLEURAL EFFUSION: A TERTIARY CARE EXPERIENCE IN CENTRAL INDIA
}

\author{
Deepak Bansal1, Sanjay Avashia², Satyendra Mishra3 ${ }^{3}$, Satyadeo Choubey4, Salil Bhargava ${ }^{5}$ \\ ${ }^{1}$ Assistant Professor Department of Pulmonary Medicine, MGM Medical College, Indore. \\ ${ }^{2} \mathrm{HOD}$ and Associate Professor, Department of Pulmonary Medicine, MGM Medical College, Indore. \\ 3 Junior Resident, Department of Pulmonary Medicine, MGM Medical College, Indore. \\ ${ }^{4}$ Assistant Professor, Department of Pulmonary Medicine, MGM Medical College, Indore. \\ ${ }^{5} \mathrm{HOD}$ and Professor, Department of Pulmonary Medicine, Bundelkhand Medical College, Sagar.
}

\section{ABSTRACT}

Medical thoracoscopy is a minimally invasive, highly useful investigation in patients with undiagnosed pleural effusions where TB and malignant pleural effusion are clinical possibilities. Semirigid thoracoscopy is an easy outpatient procedure, done under local anaesthesia with lesser duration of hospital stay. We analysed our initial 4-year record of thoracoscopy in the Department of Pulmonary Medicine, MGM Medical College, Indore.

\section{MATERIALS AND METHODS}

This cross-sectional retrospective study was done to analyse our experience of medical thoracoscopy conducted between June 2012 and May 2016. Thoracoscopy was performed for diagnosis of undiagnosed pleural effusions and data of the patients were collected retrospectively and analysed.

\section{RESULTS}

Of 63 patients with proven pleural malignancy, the majority of them (61.8\%) had adenocarcinoma, followed by small cell carcinoma (19\%). Squamous cell carcinoma and lymphoma each was diagnosed in six patients, while only three had mesotheliomas and the remaining three patients had undifferentiated pleural cancer. In 30 (29.4\%) out of 102 patients, thoracoscopic pleural biopsy showed granulomatous inflammation consistent with TB. There was no major complication or mortality related to the procedure.

\section{CONCLUSION} yield.

Medical thoracoscopy is simple, safe, an easy outpatient, convenient and cost-effective procedure with a high positive diagnostic

\section{KEYWORDS}

Thoracoscopy, Pleural Effusion, Semirigid, Malignancy.

HOW TO CITE THIS ARTICLE: Bansal D, Avashia S, Mishra S, et al. Utility of semirigid thoracoscopy in the diagnosis of recurrent undiagnosed pleural effusion: A tertiary care experience in central India. J. Evolution Med. Dent. Sci. 2016;5(74):5430-5433, D0I: 10.14260/jemds/2016/1230

\section{INTRODUCTION}

Medical thoracoscopy is used for cases of exudative pleural effusions in which a definitive diagnosis cannot be reached by conventional diagnostic methods for the diagnosis of pleural diseases. The conventional methods include clinical, radiological, laboratory and cytological investigations, which are performed routinely in many clinics. Medical thoracoscopy is performed mainly with a rigid thoracoscope or semirigid thoracoscope under mild sedation and local anaesthesia in an endoscopy room with basic monitoring. Direct inspection of the entire visceral and parietal as well as biopsies can be taken from suspicious sites under direct vision through medical thoracoscopy. Medical thoracoscopy is having high diagnostic efficiency in diagnosis of malignant pleural involvement, tuberculosis pleurisy, benign asbestos pleurisy, rheumatoid arthritis and drug-induced pleurisy. ${ }^{1}$

Financial or Other, Competing Interest: None.

Submission 08-08-2016, Peer Review 01-08-2016,

Acceptance 08-09-2016, Published 14-09-2016.

Corresponding Author:

Dr. Deepak Bansal,

11/2 Murai Mohalla,

Sanyogitaganj,

Indore.

E-mail: drbansaldeepak@gmail.com

DOI: $10.14260 /$ jemds/2016/1230
Semirigid thoracoscope is a pleural endoscope having both flexible and rigid features making it useful mainly for diagnostic purposes. The body of semirigid thoracoscope is similar to that of a fibreoptic bronchoscope, to which specialists in chest diseases are accustomed. So the problems related to early learning period are not encountered during manipulations in practices. Biopsies taken with flexible forceps are usually sufficient for histopathological diagnosis. The disadvantage of semirigid thoracoscope is that it cannot efficiently open the fibrous adherences in the pleural space. Hence, its usage in patients with pleural adherence and thickening is risky. ${ }^{1}$

Medical thoracoscopy is a minimally invasive procedure, which can be done as a day-care procedure under intravenous sedation and local anaesthesia in spontaneously breathing patient $^{2}$. On the other hand, video-assisted thoracoscopic surgery (VATS) is conducted under general anaesthesia with single lung ventilation. ${ }^{3}$ The major indication for medical thoracoscopy is evaluation of exudative pleural effusions which remain undiagnosed after pleural fluid analysis which comprise of ADA, routine and microscopic and three negative pleural fluid cytology samples for malignant cells. In these cases, large pleural biopsy specimens taken under direct vision have greater diagnostic yield up to 90 percent 4 . Diagnosis of pleural TB can be made in $99 \%$ of patients with the help of thoracoscopy. ${ }^{5}$ 
In case of suspected pleural malignancy, diagnosis can be made in $95 \%$ of patients by thoracoscopic pleural biopsy as against $44 \%$ patients using closed pleural biopsy. ${ }^{5}$ Medical thoracoscopy can be used for therapeutic procedures, such as evacuation of pleural fluid and adhesiolysis in patients with empyema, pleurodesis in patients with recurrent spontaneous pneumothorax and malignant pleural effusion. 3,6

\section{MATERIAL AND METHODS}

This was a retrospective study conducted in the Department of Pulmonary Medicine, MGM Medical College, Indore between June 2012 and May 2016. We performed thoracoscopy for diagnosis of undiagnosed pleural effusions. Undiagnosed pleural effusion was defined as failure to achieve a diagnosis by initial pleural fluid analysis, including cell count, sugar, protein, adenosine deaminase (ADA), Gram's stain, Acid-fast bacilli (AFB) smear and culture and at least three pleural fluid analyses negative for malignant cells. All patients underwent a detailed clinical history, a thorough clinical examination was carried out and all patients were subjected to laboratory investigations such as haematological profile, blood sugar, liver function and renal function tests, coagulation profile, HIV, HbsAg and hepatitis-C viral antigen, chest radiograph, ultrasonography of thorax and CT Chest.

Pregnant women, patients with blood coagulation disorders, patients having comorbid conditions like coronary artery disease, cerebrovascular disease, chronic liver disease and chronic kidney disease, haemodynamic instability, arrhythmias, intractable cough, absence of sufficient gap in the pleural space, presence of intense adherences, comatose or unconscious patient, type 2 severe respiratory failure, superior vena cava syndrome, patients with poor lung function, severe pulmonary hypertension, end-stage pulmonary fibrosis patients having excessive rib crowding, and patients not willing to give consent for thoracoscopy were excluded.

Patients were kept fasting for six hours before the procedure. A peripheral intravenous line was secured in the upper limb on the opposite side of thoracoscopy. The patient was placed in lateral decubitus position with the affected side upward and the arms of the patient put above the head to prevent the arms from interfering in the procedure. A pulse oximeter finger probe was attached to monitor the pulse rate and the arterial oxygen saturation of the patient. The procedure was done in local anaesthesia under conscious sedation with midazolam $(0.05 \mathrm{mg} / \mathrm{kg}$ body weight). The lateral chest wall was cleaned with povidone iodine, skin, subcutaneous tissue, intercostal muscle and parietal pleura were infiltrated with $10 \mathrm{~mL}$ to $15 \mathrm{~mL}$ of $2 \%$ lignocaine. A skin incision of about $1.5 \mathrm{~cm}$ was made in the $5^{\text {th }}$ or 6 th intercostal space in the posterior-axillary line to create a single port of entry into the pleural space. Subcutaneous tissue and intercostal muscles were bluntly dissected to insert the cannula with trocar into the pleural cavity.

Trocar was then removed and semirigid endoscope was inserted through the cannula. Pleural fluid was suctioned through the cannula to visualise the pleural surfaces clearly. The thoracoscope was rotated within the pleural cavity to visualise the visceral, costal and the diaphragmatic pleura. An adequate biopsy was taken from an abnormal and infiltrated area by means of the biopsy forceps. After the biopsy was taken, the cannula and the semirigid endoscope was removed and a chest tube (26 F to $32 \mathrm{~F}$ ) was inserted and connected to an underwater seal. The chest drain was taken out once the lung expanded and the secretion from the chest drain reduced to less than $50 \mathrm{~mL}$ for 3 successive days.

\section{RESULT \\ DEMOGRAPHIC CHARACTERISTIC RESULT \\ Age and Sex distribution}

The majority of the patients in our study were male. Male: female ratio was 60:42. The age of the patients ranged between years with a mean of 58 years.

\begin{tabular}{|c|c|c|c|c|}
\hline $\begin{array}{c}\text { Age } \\
\text { Group } \\
\text { (Years) }\end{array}$ & Male & Female & $\begin{array}{c}\text { Total } \\
\text { No. }\end{array}$ & $\begin{array}{c}\text { Frequency } \\
\text { \% }\end{array}$ \\
\hline $21-30$ & 2 & 0 & 2 & $1.96 \%$ \\
\hline $31-40$ & 3 & 3 & 6 & $5.9 \%$ \\
\hline $41-50$ & 10 & 8 & 18 & $17.6 \%$ \\
\hline $51-60$ & 21 & 14 & 35 & $34.3 \%$ \\
\hline $61-70$ & 16 & 12 & 28 & $27.4 \%$ \\
\hline $71-80$ & 8 & 5 & 13 & $12.7 \%$ \\
\hline Total & $\mathbf{6 0}$ & $\mathbf{4 2}$ & $\mathbf{1 0 2}$ & \\
\hline \multicolumn{5}{|c|}{ Table 1 } \\
\hline
\end{tabular}

\section{The Residence}

The distribution of carcinoma lung and tuberculosis was almost equal in both rural and urban as shown in Table- 2 .

\begin{tabular}{|c|c|c|c|c|}
\hline Residency & $\begin{array}{c}\text { Total } \\
\text { No. } \\
(\%)\end{array}$ & $\begin{array}{c}\text { TB. No. } \\
\mathbf{( \% )}\end{array}$ & $\begin{array}{c}\text { Ca Lung } \\
\text { No. (\%) }\end{array}$ & $\begin{array}{c}\text { No. } \\
\text { Diagnosis }\end{array}$ \\
\hline Rural & $\begin{array}{c}52 \\
(51 \%)\end{array}$ & $\begin{array}{c}14 \\
(46.7 \%)\end{array}$ & $\begin{array}{c}33 \\
(52.4 \%)\end{array}$ & $\begin{array}{c}5 \\
(55.6 \%)\end{array}$ \\
\hline Urban & $\begin{array}{c}50 \\
(49 \%)\end{array}$ & $\begin{array}{c}16 \\
(53.3 \%)\end{array}$ & $\begin{array}{c}30 \\
(47.6 \%)\end{array}$ & $\begin{array}{c}4 \\
(44.4 \%)\end{array}$ \\
\hline Total & $\mathbf{1 0 2}$ & $\mathbf{3 0}$ & $\mathbf{6 3}$ & $\mathbf{9}$ \\
\hline \multicolumn{5}{|c|}{ Table 2 } \\
\hline
\end{tabular}

\section{Smoking Habit}

Smoking habit was found in the majority of the male patients, 54 patients out of total 60 males were smokers which constitute about $90 \%$ with mean 30 -pack years. On the other hand none of female patients ever smoked as shown in Table 3.

\begin{tabular}{|c|c|c|c|}
\hline $\begin{array}{c}\text { H/o } \\
\text { Smoking }\end{array}$ & $\begin{array}{c}\text { Total } \\
\text { No. }\end{array}$ & $\begin{array}{c}\text { Frequency } \\
\mathbf{\%}\end{array}$ & $\begin{array}{c}\text { Mean Pack } \\
\text { Years }\end{array}$ \\
\hline Male & 54 & 90 & 30 \\
\hline Female & 00 & 00 & 00 \\
\hline \multicolumn{4}{|c|}{ Table 3 } \\
\hline
\end{tabular}

\section{Histopathological Diagnoses}

\begin{tabular}{|l|c|c|c|}
\hline \multicolumn{1}{|c|}{ Types } & $\begin{array}{c}\text { Male No. } \\
\text { (\%) }\end{array}$ & $\begin{array}{c}\text { Female } \\
\text { No. (\%) }\end{array}$ & $\begin{array}{c}\text { Total No. } \\
\text { (\%) }\end{array}$ \\
\hline $\begin{array}{c}\text { Malignant Pleural } \\
\text { Effusion }\end{array}$ & $\mathbf{4 0 ( 6 3 . 5 )}$ & $\mathbf{2 3 ( 2 2 . 5 )}$ & $\mathbf{6 3 ( 6 1 . 8 )}$ \\
\hline 1. Adenocarcinoma & 18 & 15 & $33(52.4)$ \\
\hline $\begin{array}{l}\text { 2. Squamous cell } \\
\text { carcinoma }\end{array}$ & 04 & 02 & $06(9.5)$ \\
\hline $\begin{array}{l}\text { 3. Small cell } \\
\text { carcinoma }\end{array}$ & 09 & 03 & $12(19)$ \\
\hline 4. Mesothelioma & 03 & 00 & $03(4.7)$ \\
\hline
\end{tabular}




\begin{tabular}{|c|c|c|c|}
\hline 5. Lymphoma & 03 & 03 & $06(9.5)$ \\
\hline 6. Undifferentiated & 02 & 01 & $03(4.7)$ \\
\hline Tuberculosis & $16(53.3)$ & $14(46.7)$ & $30(29.4)$ \\
\hline No diagnosis made & 05 & 04 & $09(8.8)$ \\
\hline Total & $60(58.8)$ & $42(41.2)$ & 102 \\
\hline \multicolumn{4}{|c|}{ Table 4} \\
\hline
\end{tabular}

During the study period of four years, 102 patients (58.8\% male and $41.2 \%$ female) with undiagnosed exudative pleural effusion underwent thoracoscopy. Mean age of the patients was 58 years of mean age. A diagnosis could be established in 93 of the 102 patients by medical thoracoscopy. Right side pleural effusion is much commoner than left with ratio - 67:35. Pathologic diagnostic details are demonstrated in Table 1. The diagnostic yield for thoracoscopic pleural biopsy was $90.2 \%$. No major complications of thoracoscopy were observed.

Of 63 patients with proven pleural malignancy, the majority of them (61.8\%) had adenocarcinoma, followed by small cell carcinoma (19\%). Squamous cell carcinoma and lymphoma each was diagnosed in six patients, while only three had mesothelioma and the remaining three patients had undifferentiated pleural cancer. In 30 (29.4\%) out of 102 patients, thoracoscopic pleural biopsy showed granulomatous inflammation consistent with TB with almost equal male and female distribution. In nine out of $102(8.8 \%)$ patients with pleural effusion, the thoracoscopic pleural biopsy did not reveal any specific diagnosis.

\section{DISCUSSION}

\begin{tabular}{|c|c|c|c|c|c|c|c|c|c|c|}
\hline \multirow[t]{2}{*}{ 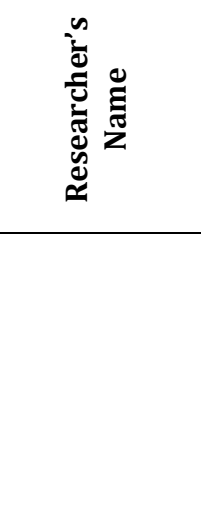 } & \multirow[t]{2}{*}{$\stackrel{\pi}{0} \Xi$} & \multirow[t]{2}{*}{ 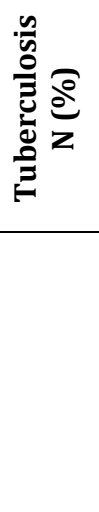 } & \multirow[t]{2}{*}{ 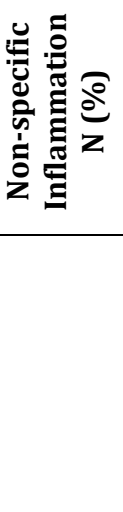 } & \multirow[t]{2}{*}{ 尝 } & \multicolumn{6}{|c|}{ 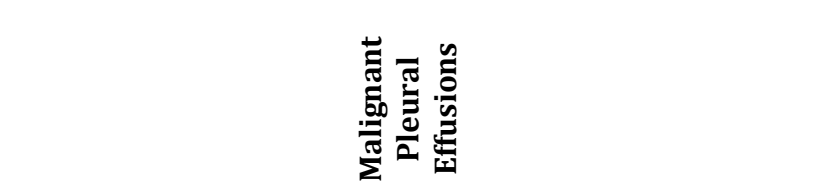 } \\
\hline & & & & & 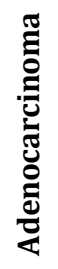 & 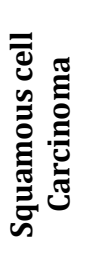 & 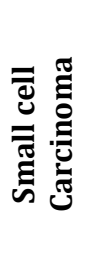 & 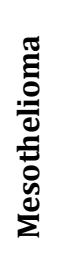 & 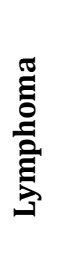 & 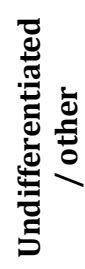 \\
\hline $\begin{array}{l}\text { Sodhi et al. } \\
(2015)^{6}\end{array}$ & 47 & 5 & 5 & 33 & 10 & 1 & 2 & 10 & 1 & 19 \\
\hline $\begin{array}{c}\text { Aggarwal A } \\
\text { et al. }(2014)^{7}\end{array}$ & 19 & 3 & 3 & 13 & 10 & - & - & 1 & - & 2 \\
\hline $\begin{array}{l}\text { Prabhu VG. et } \\
\text { al. }(2012)^{8} \\
\end{array}$ & 68 & 16 & 22 & 24 & 15 & - & - & 3 & 1 & 12 \\
\hline $\begin{array}{l}\text { Mootha VK et } \\
\text { al. }(2011)^{2}\end{array}$ & 35 & 8 & 9 & 17 & - & - & - & 1 & 1 & 15 \\
\hline $\begin{array}{l}\text { Mehta A. et } \\
\text { al. (2010) } \\
\end{array}$ & 25 & 2 & 22 & 9 & 5 & - & - & - & - & 4 \\
\hline $\begin{array}{c}\text { Tscheikuna J. } \\
\text { et al. } \\
(2009)^{10} \\
\end{array}$ & 86 & - & - & 39 & - & - & - & - & - & - \\
\hline $\begin{array}{c}\text { Wang Z et al. } \\
(2008)^{11}\end{array}$ & 27 & 6 & 5 & 15 & 5 & - & - & 2 & - & 8 \\
\hline $\begin{array}{l}\text { Blanc FX et } \\
\text { al. }(2002)^{12}\end{array}$ & 149 & 4 & 65 & 80 & - & - & - & - & - & - \\
\hline $\begin{array}{c}\text { Kendall } \\
\text { et al.(1992) }\end{array}$ & 48 & - & 8 & 24 & - & - & - & - & - & - \\
\hline $\begin{array}{c}\text { Jindal S } \\
\text { et al.(2015) } 14\end{array}$ & 25 & 2 & 2 & 20 & 8 & 1 & - & 7 & 1 & 1 \\
\hline $\begin{array}{c}\text { Bansal D. } \\
\text { et al }(2016)^{*}\end{array}$ & 102 & 30 & 09 & 63 & 33 & 6 & 12 & 3 & 6 & 3 \\
\hline
\end{tabular}

*Present study

In this study, we have presented the data of 102 patients who underwent thoracoscopy for the diagnosis of undiagnosed pleural effusions. We included patients with undiagnosed pleural effusions for thoracoscopy in whom initial diagnostic work-up with pleural fluid analysis, including pleural fluid routine microscopic, ADA and three pleural fluid cytologies were inconclusive. The yield of thoracoscopic pleural biopsy was $90.2 \%$ (91/102) patients in this group.

This high yield is comparable with other studies such as Sodhi et al ${ }^{6}(87.23 \%)$, Aggarwal A et al $^{7}$ (69\%) , Jindal S et al 14
( $92 \%$ ) Wang Z et al ${ }^{11}(93 \%)$, Tscheikuna et al ${ }^{10}$ (95\% ), Kendall et $\mathrm{al}^{13}$ (83\%), Mootha V K et al ${ }^{2}(74.3 \%)$, Mehta A et al $(2010)^{9}(80 \%)$ and Prabhu VG et al $^{8}(97 \%)$.

The majority of the undiagnosed pleural effusion in the present study found out to be malignant $61.8 \%(63 / 102)$ which is similar to the experience of various centres like Tscheikuna et al ${ }^{10} 70 \%$, Blanc FX et $\mathrm{al}^{12} 53.7 \%$, V K Mouse et $\mathrm{al}^{2} 45.7 \%$ showing a majority of the yield to be malignant. Adenocarcinoma is the most common subtype reported in undiagnosed pleural effusions. In our study, 33 of the 63 
(52.4\%) patients were diagnosed to have adenocarcinoma. Similar observations were reported in other studies by Aggarwal A et al $^{7}$ 10/13, Prabhu VG et al ${ }^{8}$ 15/24 and Jindal S et $\mathrm{al}^{14} 8 / 20$.

Mesothelioma $(3 / 63=4.7 \%)$ is the least common cause of malignant effusions in our study, which is in concordance with the study of Mootha VK et al $^{2}$ who had pleural metastasis as the more common aetiology of malignant effusion $(16 / 17=$ $94.1 \%)$ than mesothelioma $(1 / 17=5.9 \%)$.

In our study, TB was found to be the common cause of undiagnosed effusion diagnosed in 30 out of 102 patients (29.4\%). Similar incidences of TB were made by Mootha VK et $\mathrm{al}^{2}(8 / 35=22.9 \%)$ and Prabhu VG. et al. $(2012)^{8}(16 / 68=$ $23.53 \%)$.

\section{CONCLUSIONS}

The results of this study suggest that medical thoracoscopy is a minimally invasive, highly useful investigation in patients with undiagnosed pleural effusions where TB and malignant pleural effusion are clinical possibilities. Biopsy specimens obtained with medical thoracoscopy are sufficient to establish a proper histopathological diagnosis with sufficient reserve sample for immunohistochemistry. Semirigid thoracoscopy is an easy outpatient procedure, done under local anaesthesia with lesser duration of hospital stay. It is a simple technique and can be easily mastered by anyone who handles bronchoscope because of its convenience and compatibility with existing bronchoscopy. It has a low complication rate even in newer hands. In short, thoracoscopy is simple, safe, convenient and cost-effective with a high positive diagnostic rate; a more widely performed procedure.

\section{REFERENCES}

1. Metintaş M. Medical thoracoscopy at 105. Anniversary. Eurasian J Pulmonol 2015;17(3):129-35.

2. Mootha VK, Agarwal R, Singh N, et al. Medical thoracoscopy for undiagnosed pleural effusions: experience from a tertiary care hospital in north India. Indian J Chest Dis Allied Sci 2011;53(1):21-4.
3. Casal RF, Eapen GA, Morice RC, et al. Medical thoracoscopy. Curr Opin Pulm Med 2009;15(4):313-20.

4. Loddenkemper R. Thoracoscopy: state of the art. Eur Respir J 1998;11(1):213-21.

5. Loddenkemper R, Grosser H, Gabler A, et al. Prospective evaluation of biopsy methods in diagnosis of malignant pleural effusions: intra patient comparison between pleural fluid cytology, blind needle biopsy and thoracoscopy. Am Rev Respir Dis 1983;127(Suppl 4):114.

6. Sodhi R, Sindhwani G, Nadia S, et al. A three-year experience of medical thoracoscopy at a tertiary care center of Himalayan region. J Cardio Thorac Med 2016;4(1):397-402.

7. Agarwal A, Prasad R, Garg R, et al. Medical thoracoscopy: a useful diagnostic tool for undiagnosed pleural effusion. Indian J Chest Dis Allied Sci 2014;56(4):217-20.

8. Prabhu VG, Narasimhan R. The role of pleuroscopy in undiagnosed exudative pleural effusion. Lung India 2012;29(2):128-30.

9. Mehta A, Rajesh V, Vishwam D, et al. Value of semi rigid thoracoscopy in pleural effusion. Pulmon 2010;12:43-5.

10. Tscheikuna J, Silairatana S, Sangkeaw S, et al. Outcome of medical thoracoscopy. J Med Assoc Thai 2009;92(Suppl 2):S19-23.

11. Wang Z, Tong ZH, Li HJ, et al. Semi-rigid thoracoscopy for undiagnosed exudative pleural effusion: a comparative study. Chin Med J 2008;121(15):1384-9.

12. Blanc FX, Atassi K, Bignon J, et al. Diagnostic value of medical thoracoscopy in pleural disease: a 6-year retrospective study. Chest 2002;121(5):1677-83.

13. Kendall SW, Bryan AJ, Large SR, et al. Pleural effusions: is thoracoscopy a reliable investigation? A retrospective review. Respir Med 1992;86(5):437-40.

14. Jindal S, Gangajalia CA, Parikh $P$, et al. Medical thoracoscopy: a retrospective analysis in a tertiary care centre. Int J Adv Med 2015;2(1):30-3. 